\title{
OSCILLATORY BEHAVIOR OF SECOND ORDER NONLINEAR DELAY DIFFERENTIAL EQUATIONS WITH POSITIVE AND NEGATIVE NEUTRAL TERMS
}

\author{
SAID R. GRACE, John R. GRAEF AND IRENA JADlovskÁ
}

\begin{abstract}
The aim of the paper is to initiate a study of the oscillation of solutions of second order nonlinear differential equations with positive and negative nonlinear neutral terms. The results are illustrated by some examples.
\end{abstract}

Mathematics subject classification (2010): 34C10, 34K11.

Keywords and phrases: Nonlinear differential equation, delay, second-order, neutral term, oscillation.

\section{REFERENCES}

[1] R. P. Agarwal, M. Bohner, T. Li, AND C. ZHANG, Oscillation of second-order differential equations with a sublinear neutral term, Carpathian Journal of Mathematics 30 (2014), 1-6.

[2] M. BOHNER, S. R. GRACE, AND I. JADLOVSKÁ, Oscillation criteria for second-order neutral delay differential equations, Electron. J. Qual. Theory Differ. Equ. 2017 (2017), No. 60, 1-12.

[3] T. CANDAN AND R. S. DAHIYA, Oscillation of mixed neutral differential equations with forcing term, in: "Dynamical Systems and Differential Equations (Wilmington, NC, 2002)", Discrete Contin. Dyn. Syst. 2003, suppl., 167-172.

[4] P. DAS, Oscillations of mixed neutral equations caused by several deviating arguments, Bull. Calcutta Math. Soc. 86 (1994), 135-146.

[5] S. R. GRACE, Oscillatory behavior of second-order nonlinear differential equations with a nonpositive neutral term, Mediterr. J. Math. 14 (2017), Art. 229, 12pp.

[6] S. R. GRACE AND J. R. GRAEF, Oscillatory behavior of second order nonlinear differential equations with a sublinear neutral term, Mathematical Modelling and Analysis, 30 (2018), 217-226.

[7] J. K. Hale, Functional Differential Equations, Applied Mathematical Sciences, Vol. 3, SpringerVerlag, New York, 1971.

[8] G. H. Hardy, I. E. Littlewood, and G. Polya, Inequalities, Cambridge University Press, Cambridge, Mass, USA, 1959.

[9] R. G. Koplatadze And T. A. Chanturiya, Oscillating and monotone solutions of first-order differential equations with deviating argument (in Russian), Differ. Uravn. 18 (1982), 1463-1465.

[10] G. LADAS AND I. P. STAVROULAKIS, Oscillation caused by several retarded and advanced arguments, J. Differ. Equations, 44 (1982), 134-152.

[11] H. LI, Z. HAN, AND Y. SUN, Existence of non-oscillatory solutions for second-order mixed neutral differential equations with positive and negative terms, Int. J. Dyn. Syst. Differ. Equ. 7 (2017), 259271.

[12] T. Li And Y. V. Rogovchenko, Oscillation of second-order neutral differential equations, Math. Nachr. 288 (2015), 1150-1162.

[13] T. Li AND Y. V. Rogovchenko, Oscillation criteria for even-order neutral differential equations, Appl. Math. Lett. 61 (2016), 35-41.

[14] T. Li, Y. V. RogovCHENKO, AND C. ZHANG, Oscillation of second-order neutral differential equations, Funkcial. Ekvac. 56 (2013), 111-120.

[15] CH. G. Philos, On the existence of nonoscillatory solutions tending to zero at $\infty$ for differential equations with positive delays, Arch. Math. (Basel) 36 (1981), 168-178.

[16] Y. Qi AND J. YU, Oscillation of second order nonlinear mixed neutral differential equations with distributed deviating arguments, Bull. Malays. Math. Sci. Soc. 38 (2015), 543-560. 
[17] S. Selvarangam, B. Rani, And E. Thandapani, Some new oscillation theorems for secondorder Euler-type differential equations with mixed neutral terms, Adv. Pure Appl. Math. 8 (2017), $163-173$.

[18] H. SHI AND B. YUZHEN, Oscillatory behavior of a second order nonlinear advanced differential equation with mixed neutral terms, Adv. Difference Equ. 2019 (2019), No. 468, 18 pp.

[19] S. TAMILVANAN, E. ThandaPANI, AND J. DŽURINA, Oscillation of second order nonlinear differential equations with sub-linear neutral term, Differ. Equ. Appl. 9 (2017), 29-35.

[20] E. TunÇ AND O. ÖZDEMIR, On the oscillation of second-order half-linear functional differential equations with mixed neutral term, J. Taibah Univ. Science 13 (2019), 481-489.

[21] R. XU AND F. MEng, Some new oscillation criteria for second order quasi-linear neutral delay differential equations, Appl. Math. Comput. 182 (2006), 797-803. 